\title{
Holisztikus fogalom és (meta)elméleti kategória
}

A szerző azt javasolja az NHIT tagjainak, hogy álláspontjukat ne tudományos igazságként vagy hipotézisként definiálják, hanem közpolitikai ajánlásként. Érveket hoz fel az „információs társadalom” kategória elfogadása mellett: (a) Magyarország az információs társadalommá válás küszöbén áll, tudástársadalommá csak hosszú távon válhat. (b) Az Európai Unió a legtöbb hivatalos dokumentumban az információs társadalom fogalmát használja. A szerző elveti az információs társadalom fogalmának leszűkített, technológiaközpontú értelmezését. Kifejti, hogy ezt a fogalmat az érintett tudományágak és az integrált metaelmélet szerint nem lehet és nem is szabad az NHIT állásfoglalása szerint értelmezni, fogalmi skatulyába szorítani.

Kulcsszavak: információs társadalom, tudástársadalom, integrált metaelmélet, holisztikus felfogás

\section{Szerzői információ:}

\section{Varga Csaba}

Társadalomelmélettel és társadalomfejlesztéssel foglalkozó szociológus, címzetes egyetemi docens. Az ELTE BTK szociológia szakán végzett, a Stratégiakutató Intézet elnöke és a Veszprémi Egyetemen az e-közigazgatási kutatócsoport társelnöke. Fontosabb kutatási területei: globalizáció és lokalizáció (1993-tól), az információs társadalom elmélete és gyakorlata (1993-tól), a tudás- és tudattársadalom elmélete (1995-tól), metaelmélet-metafilozófia, az új tudomány elmélete (2002-tól). Az információs korról szóló INCO címú folyóirat fốszerkesztốje és az eVilág címú folyóirat szerkesztóbizottságának elnöke. Új könyvei: A legutolsó utolsó esély (Kiss Endrével, Stratégiakutató Intézet, 2001); Új elmélethorizontok elött (Budapest: Tertia, 2004), Metaelmélet, metafilozófia (szerk., Stratégiakutató Intézet, 2005).

www.vargacsaba.hu; www.strategiakutato.hu; www.metaelmelet.hu E-mail: vargacs@strategiakutato.hu

\section{Így hivatkozzon erre a cikkre:}

Varga Csaba. „Holisztikus fogalom és (meta)elméleti kategória”.

Információs Társadalom VI, 1. szám (2006): 40-43.

https://dx.doi.org/10.22503/inftars.VI.2006.1.5

A folyóiratban közölt müvek

a Creative Commons Nevezd meg! - Ne add el! - Így add tovább! 4.0

Nemzetközi Licenc feltételeinek megfelelöen használhatók. 
Varga Csaba

\section{Holisztikus fogalom és (meta)elméleti kategória}

\section{Reflexiók}

1. Csak kellő iróniával lehet szemlélni azt a helyzetet, hogy van egy félállami, ám alapvetôen hivatalos, kormányzati tanács, amely ugyanakkor önmagát az információs társadalom bölcsének minôsíti, $s$ az információs társadalom átfogó, holisztikus fogalma ${ }^{1}$ mellett kardoskodik, miközben a tanács - hírközlési és informatikai - neve tagadja a tanács által adott fogalmi értelmezést. Normális országban az ilyen kellemesen abszurd helyzeteket mindennemú bölcsek csak iróniával képesek elviselni. Mindenesetre magam honorálom, hogy már legalább a félállami tanácsban bölcsek ülnek.

2. Amikor az információs társadalom állásfoglalás elkészült, egyrészt biঞalmatlanul fogadtam, mert egy kelet-közép-európai vagy egy magyar értelmiségiben meglehetősen rossz emlékeket idéz fel, amikor az állam vagy az állami-félállami szervezet kollektív véleményként tudományos vitát kíván eldönteni; ez a bizalmatlanság független attól, hogy az állásfoglalás szemléletével egyébként jórészt egyetértek. Mindenesetre javaslom a tanács tagjainak, hogy álláspontjukat politikai-közpolitikai ajánlásnak és - ettól elválasztva -semmi esetre sem tudományos igazságnak vagy hipotézisnek definiálják. Az önmagát komolyan vevố tudományban (különösen a poszt-normál tudományban) a világ összes bölcs tudósa sem dönthet egyetlen tézisról sem, hiszen mindig jön egy következő újabb gondolkodó, akit először ugyan kitagadnak a korszellem dogmái miatt, de aki akár évszázadok óta elfogadott igazságokat cáfol meg.

3. Az elkészült információs társadalom állásfoglalást másrészt bizalommal kezdtem el tanulmányozni, mert magam is helyes törekvésnek tartom, hogy a politika, a kormányzat, a nemzeti fejlesztési terv nagyjából azonos tartalommal ugyanazt a fogalmat használja. Ez azonban nem tudományos kérdés, viszont politikai-közpolitikai probléma, mert Magyarországon jelenleg a politikusok többsége (kivéve néhány tucat szakpolitikust) általában nem érti az információs társadalom fogalmát. Magam azonban két másik érvet hozok fel az információs társadalom kategória elfogadása mellett: a) Magyarország ebben az évtizedben legjobb esetben az információs társadalom korszakába jut el, így legfeljebb hosszabb távú célkitűzésként lehetne a tudástársadalom fogalmát érvényesíteni. b) Az Európai Unió a legtöbb hivatalos dokumentumban az információs társadalom fogalmát használja, ámbár a lisszaboni program - ki tudja, milyen megfontolásból tudásalapú gazdaságról beszél.

4. Ez az állásfoglalás helyesen lezár egy több mint egy évtizedes vitát: elveti az információs társadalom jelentôsen leszúkittett, technológia-központú fogalomértelmezését.

\footnotetext{
${ }^{1}$ A Stratégiakutató Intézet a komplex, ,holisztikus" fogalmat 1997-ben dolgozta ki és publikálta: A mai világ és a jövố forgatókönyvei (HÉA Stratégiakutató Intézet, MTA Szociológiai Intézet, Magyar Kapu Alapítvány, 1997), majd A tudás társadalma, I-II. (Stratégiakutató Intézet, Ipargazdasági Kutató és Tanácsadó Kft., Nemzeti Ifjúságkutató Intézet, 2002).
} 
Számos publikációból és magánlevélból (és e-mailból) idézhetnék, amelyben fóként jeles informatikusok hevesen, elfogultan tagadták az informatikai szemlélet kibóvítését az információs társadalomra, azaz a tudás- és társadalomfejlesztésre is kiterjedô felfogását.

A magyar kis abszurd jellemzóje persze az is, hogy az érdekelt tárcát a mai napig informatikai minisztériumnak hívják, s alig egy hete a tárca egyik bölcse még arra intette a vitázókat, hogy ne felejtkezzenek meg arról, hogy ez a minisztérium müszaki-technológiai minisztérium. Magam abban bizakłodom, hogv az NHIT (minden irónia nélkül mondom) kitúnôségei most már azért harcolnak, hogy az MITS jelenlegi - a gördülő tervezés szerinti - átdolgozásánál ez a holisztikus információstársadalom-felfogás érvényesüljön, hiszen a 2003. évi MITS-ból éppen azért maradt ki a harmadik pillér, mert akkor nem lehetett a tárca szakértôivel és vezetốivel elfogadtatni a társadalomra, gazdaságra, emberre kiterjedô szemléletet.

5. A többi töprengés tudományos vita tárgya, ám ez az állásfoglalás szerint mesterséges és felesleges, sốt meddő definíciós csata. Ám azért lássunk néhány tézist:

- Az információs társadalom fogalma, különösen az információ szó információtudományi szempontból aggályos. Csorba József kutatásai ${ }^{2}$ egyértelműen jelzik, hogy az információ fogalma angolul mennyire leszúkített tartalmú, és nem keverhető össze a knowledge kategóriájával sem, aminek értelmét magyarul nem a tudás, hanem ennél egy szintén szúkebb fogalom, az ismeret adja vissza. Az angol intelligens (intelligent) kifejezés tehát magyarul a tudással azonosítható.

- Az információs társadalom fogalmában a kategória második szava, a társadalom szintén aggályos, mindenekelótt azért, mert a társadalomtudományban és a közpolitikában egyaránt tisztázatlan a társadalom és a társadalomfejlesztés kategóriája is. Nem meglepő, hogy az NHIT álláspontja ezt meg sem kísérli tisztázni, s jobb híján az „egész társadalom komplexuma” homályos megfogalmazást használja. (Az ezzei kapcsolates kutatásaim és fogalomértelmezéseim visszakereshetók. $)^{3}$

- Az információs társadalom fogalma történelemsaciológiai đa zefüggésḅen nem generális, hanem konkrét korszakhoz kötött értelmú. Az információs kor valamikor a 70 -es évek elejétól-közepétól indul, ś a különbözố összetett fogalmak (informatikai - azaz technológia-központú - társadalom; információs - azaz információ-központú - társadalom; tudás - azaz tudás- [tehát ismeret] központú - társadalom) történeti változási lépcsófokokat is leíró kategóriákként értelmezhetốk.

- Az elóbbi tézisból az következik, hogy a generális fogalom az információs kor lehet, amelynek elsókorszaka a 70-es, 80-as (és részben a 90-es) évek, avagy az informatikai társadalom idốszaka, ami nálunk egészen az ezredforduló utánig ełtartott. A második korszak Európában a 90-es évek végétól, a lisszaboni programtól datálható és várhatóan eltart a 10-es évek közepéig, s közben - ha minden jól megy - folyamatosan megszületik a harmadik korszak, a tudástársadalom időszaka.

- Az elóbbi három (vagy több) különbözố fogalomnak elméletileg, sốt metaelméletileg ${ }^{4}$ akkor van létjogosultsága, ha tágabb és magasabb szintú elméletben, például a világmodellek el-

${ }^{2}$ Ez az írás egyébként az Infornációs Társadeion n :ímủ folyóiratnak ugyanabban a számában jelent meg, mint az NHIT álláspontja (2005/3. szám)!

${ }^{3}$ Lásd Varga Csaba: A három fogalom (eVilág, 2003!12); Varga Csaba (2005): Új elmélethorizontok elött (Tertia).

${ }^{4}$ Metaelmélet, metafilozófin (Stratégiakutató Intézet, 2005). 
méletében önálló, sajátos tartalmat kap. A nehézséget az is adja, hogy ebben az összefüggésben nem kerülhetô meg a globalizáció-lokalizáció problematikája, hiszen az információs társadalom egyben a globalizáció, ${ }^{5}$ sốt az univerzalizáció új modellje is.

- A metaelméleti kiindulópontú és horizontú jövóelmélet szempontjából megint másként definiálható az információs társadalom. Ma talán ez a legérdekesebb. Európa elốt jelenleg három reális alternativa van: 1 . vissza a régi modellekhez, vissza a régi gondolkodásmódokhoz, idekötôdik az újszocializmus és az újkapitalizmus, az új baloldal és az új jobboldal, az új szociáldemokrácia és az újliberalizmus, valamint az újkonzervativizmus stb.; 2. elốre a ma még újnak látszó modellekhez és az egyre kevésbé új gondolkodásmódokhoz, idetartozik a posztindusztrializmus, az információs társadalom, az ökológiai társdalom, a kreatív társadalom stb.; 3. a régi és az új modellek egyesítése az új tudások alapján és az új jövớvíziók szerint, idesorolható a fenntartható tudástársadalom, a szakrális demokrácia, az univerzális egységtársadalom stb.

A jelenlegi globális társadalomban jelen van mind a három alternatíva, de kontinensenként más-más arányban és hangsúllyal. Az első alternatíva Európában a legerôsebb, mert túl hosszú ideg tartott (és tart) a kapitalizmus, amelynek dogmatizálódott gondolkodásától és mentalitásától egyre nehezebb szabadulni. A második alternatíva leginkább Észak-Amerikában és Délkelet-Ázsiában vált uralkodóvá, noha például ÉszakEurópa fejlettebb információs társadalom, mint Ausztrália vagy Japán. A harmadik alternatíva - mint ahogy az lenni szokott - még elsôsorban szellemi modell, ám az erôs közép-európai hiedelemmel szemben nem az „objektív valóság”, hanem a „szellemi valóság" alakítja át a világot.

Nincs abban semmi meglepő, hogy az első alternatívában egyaránt benne van az egymást feltételezô két világ és két logika: a pénz- és információ-központú újkapitalizmus és önkritikájaként újra visszatérố- szükségképpen homályos - társadalmiesélyegyenlőség-központú újszocializmus. Idetartozik az újkapitalizmus által végképp felmorzsolt előző világmodell: a posztfeudális vagy nemzetállami világ és annak újra életre kelô szükségképpen homályos - konzervatív programja, amely a kapitalizmus ellentmondásait kívánja korrigálni a 19. század nemzeti ideái és otthonosságélményei szerint. És természetesen ebben a világban élt (és él ma is) belsố alternatívaként a liberális valóságvágy és gondolkodás, amely az euroatlanti individualizáció eredményeként a közösségi szabadság helyett újra a - szükségképpen homályos - egyéni szabadságot követeli. Ezekben a részalternatívákban közös, hogy a 20. század első felének valóságát vetítik rá a jelenlegi, az ezredforduló utáni világra, és gyakran képtelenek tudomásul venni, hogy az új globális-lokális valóság kardinálisan új valóság és új paradigma. Az elsố alternatíva globális valósága fokozatosan szétmállik és átalakul, Magyarországon is, bár nálunk az összetett és folyton elkésett valóság miatt még legalább egy évtizedig fennmaradhat az a látszat, hogy csak az elsố alternatíva világában élünk.

Az elsố alternatíva a 20. század közepének „talaján”, áll és vissza-visszafordul a 19. század közepének és második felének eszméihez. A második alternatíva a 20. század végének „talaján” áll, de egyelőre nem tud szabadulni a 19-20. század gondolkodásától és intézményi rendszerének gyakorlatától. Európában most nem az a legnagyobb baj,

${ }^{5}$ Kiss Endre - Varga Csaba (2001): A legutolsó utolsó esély (Stratégiakutató Intézet); Kiss Endre (2003): Globalizáció és/vagy posztmodern (Kodolányi). 
hogy az információs társadalom gazdasága (például az IKT-ipar vagy tágabban a tudásipar) nehezen gyúri le a régi és az új kapitalizmus rendjét és szabályait, hanem az, hogy Európa képtelen befogadni és alkalmazni az információs koron már túllépố új tudást és az új gondolkodást. Az információs társadalom világmodell ebbe a második alternatívába tartozik.

A harmadik alternativa - az előzô kettóhöz képest - még homályosabb, de nem csupán azért, mert a felvilágosodás utáni múltak és közelmúltak leporolása és csinosítása nem alternatíva. Paradox módon homályos például azért, mert az új globális-lokális valóságot nem a régi szemüveggel nézi, s mert az új gazdaság, az új társadalom vagy általában az új tudás szinte felfoghatatlan a régi és zárt világképek alapján. A belátható jövố már a tudás- és tudatfejlesztó társadalommodell. Ez nem pusztán a szellemi elit vágya, hiszen sokszor a fenn lévók látják a legkevésbé, hogy a jólétorvosság és a presztízsorvosság csak felületi kezelést nyújt az egyéni és kollektív betegségekre. A valóságos lélekfogyásra, a tudáshiányra, a magasabb tudatállapot ismeretlenségére vagy az istenvesztésre. Önmagában már nem tartható az objektív (külsố, racionális stb.) világ elképesztő (és részben csak látszólagos) uralma a szubjektív (belső, lelki, transzcendens stb.) felett.

Az információs társadalom fogalmát tehát az érintett tudományágak (információelmélet, társadalomelmélet, történelemszociológia, jövôelmélet stb.) vagy az integrált metaelmélet szerint nem lehet és nem is szabad az NHIT állásfoglalása szerint értelmezni, fogalmi skatulyába szorítani.

Az NHIT álláspontjának egyik tétele: „...az 'információs társadalom' fejlesztése és politikai programja nem ágazati vagy tárcafeladat, hanem a magyar társadalom, a közszféra és a gazdaság legátfogóbb jövóképét jelentố, kormányszintú, integratív összpárti/ parlamenti konszenzuson alapuló tervezési prioritás és igazodási pont”. Egyetértek. Noha két helyen kicsit pontosítanék: 1. Az Európai Unió az i2010 stratégia óta nem véletlenül beszél fenntartható információs-innovációs társadalomról. (Ez az újabb, aktuális fogalombóvítés szerintem helyes.) 2. Ez a jelenlegi legátfogóbb program csak akkor vihető végbe, ha nemcsak „kormányszintú” stratégia, hanem a magyar civil társadalom programja lesz. 